\title{
NASOPHARYNGEAL ANGIOFIBROMA. A CASE SERIES
}

\author{
G. Revanth Kumar Reddy', P. Narayana Rao²,
}

\section{HOW TO CITE THIS ARTICLE:}

G. Revanth Kumar Reddy, P. Narayana Rao. "Nasopharyngeal angiofibroma. A case series". Journal of Evolution of Medical and Dental Sciences 2013; Vol2, Issue 27, July 8; Page: 4994-4996.

ABSTRACT: - INTRODUCTION: Juvenile Nasopharyngeal Angiofibroma is a rare tumour affecting young adults. This is a case series of five cases operated at Govt. General Hospital (GGH), Guntur, Andhra Pradesh. MATERIAL AND METHODS: Five cases of JNA operated at GGH, Guntur from 2009to 2011 are presented. All patients were adolescent males and complained of epistaxis and nasal block. They were evaluated pre operatively by angiography and embolized. Four patients were treated by lateral rhinotomy and one by endoscopic approach.

RESULTS: All patients were treated successfully with minimal intra op and post op complications. Bleeding was less due to pre op embolization of all the cases.

CONCLUSION: Pre-operative embolization has resulted in less complications and success rate of surgery is also good.

KEYWORDS: Angiofibroma, embolisation

INTRODUCTION: Juvenile Nasopharyngeal Angiofibroma (JNA) is a rare benign tumour that occurs almost only in adults and young male patients $[1,2,3,4]$. It represents 0.05 to $0.5 \%$ of all head and neck tumours [5,6]. Incidence in India and Egypt is slightly higher than in USA and Europe. JNA is locally aggressive, slow growing tumour with high vasculature and tendency to persistence and recurrence $[2,3,7]$. JNA originates form vascular plexus that remains after involution of first branchial arch. Therefore in most cases, tumour receives blood supply from external carotid artery.

The tumour originates in nasopharynx in the superior part of sphenopalatine foramen $[2,6,8,9,10]$. The tumour spreads in the sub mucosal plane medially entering the nasal cavity or laterally towards pterygopalatine and infra temporal fossae. Displacement of posterior maxillary wall by the tumour-Holman-Millers sign is pathognomic for JNA.

Growth into the orbit is encountered roughly in every third patient [2]. Tumor spreads into pterygopalatine fossa through inferior orbital fissure and from ethmoid labyrinth through medial orbital wall. As a result, proptosis occurs and visual and oculomotor disorders may develop. Specific feature of spread into the orbit is displacement of tissues without their infiltration. From infratemporal fossa, the tumor can spread to middle cranial fossa; growth into sphenoid sinus and further bony destruction lead to involvement of cavernous sinus and chiasmatic-sellar region [11]. JNA, in most cases, spreads though paranasal sinuses by "pushing" of bony walls without destruction, but intracranial involvement is associated with destruction of skull base

MATERIALS AND METHODS: Five adolescent males of angiofibroma who presented to Govt. General Hospital, Guntur during years from 2009 to 2011was studied. The duration of disease prior to admission was between three months to one year. All the patients had the disease extending into the nasal cavity and nasopharynx with one patient who had minimal disease confined to the nasal cavity. In all the patients, pre-operative angiographic examination and imaging studies were 


\section{CASE REPORT}

performed and embolization was done. Surgical removal of the tumour was done by lateral rhinotomy approach in four cases and endoscopic excision in one case.

RESULTS: Four cases were operated by lateral rhinotomy approach and one case was operated by endoscopic endonasal excision. All the patients recovered well and they had no post-operative complications. There was no post-operative residual disease or recurrence during the follow up period of two years.

DISCUSSION: Selection of approach to JNA is based not only on surgeons experience but also on the number of criteria: visualization of tumour, possibilities of hemostasis, absence of facial scars and deformities and influence on growth of facial skeleton [12]. In our hospital, lateral rhinotomy is the approach most commonly used. Treatment of angiofibroma poses a surgical challenge due to its vascularity. Pre-operative embolization is an effective method of reducing the vascularity. In all the five cases there was no intra-operative bleeding and the tumour was delivered successfully. Endoscopic approach increases the visualization making this a favorable approach for localized tumours and to look for blind zones that are obscured for direct view.

The amount of blood loss during surgery was minimal. Post-operative complications were minimal and a contrast MRI was taken after six months. There was no sign of recurrence or residual disease. All the patients had good quality of life and no nasal complaints.

CONCLUSION: Treatment of nasopharyngeal angiofibroma is surgical excision. Bleeding is the most common complication during surgery of this highly vascular tumour. Pre-operative embolization significantly reduces bleeding and is recommended in all cases of angiofibroma. Lateral rhinotomy is a safe procedure and can be performed safely. Endoscopic procedure increases the visualization and extent of surgical excision.

\section{REFERENCES}

1. Andrews JC, Fisch U, Valavanis A, Aeppli U, Makek MS (1989). The surgical management of extensive nasopharyngeal angiofibroma with the infratemporal fossa approach. Laryngoscope 99:429-437.

2. Cruz AAV, Atique JMC, Melo-Filho FV, Elias J (2004) Orbital involvement in juvenile nasopharyngeal angiofibroma: prevalence and treatment. Ophth Plast Reconstr Surg 4:296300.

3. Donald PJ, Enepikedes D, Boggan J (2004) Giant juvenile nasopharyngeal angiofibroma. Arch Otolaryngol Head Neck Surg130:882-886.

4. El-Bahnawy OA, El-Dien AES, Amer T (2004) Endoscopic assisted midfacial degloving approach for type III juvenile angiofibroma. Int J Pediatr Otorhinolaryngol 68:21-28.

5. Ferreira LM, Gomes EF, Azevedo JF, Souza RF, Araujo R, Rios AS (2006) Endoscopic surgery of nasopharyngeal angiofibroma. Rev Bras Otorrinolaryngol 72(4):475-480

6. Pryor SG, Moore EJ, Kasperbauer JL (2005) Endoscopic versus traditional approaches for excision of juvenile nasopharyngeal angiofibroma. Laryngoscope 115:1201-1207.

7. Banhiran W, Casiano RR (2005) Endoscopic sinus surgery for benign and malignant nasal and sinus neoplasm. Curr Opin Otolaryngol Head Neck Surg 13:50-54. 
8. Cansiz H, Güvenç MG, Şekercioğlu N (2006). Surgical approaches to juvenile nasopharyngeal angiofibroma. J CraniomaxillofacSurg 24:3-8.

9. Önerci TM, Yücel ÖT, Öğretmenoğlu O (2003) Endoscopic surgery in treatment of juvenile nasopharyngeal angiofibroma. Int J Pediatr Ororhinolaryngol 67:1219-1225.

10. Roger G, Tran Ba Huy P, Froehlich P, Van Den Abbelle T, Klossek JM, Serrano E, Garabedian EN, Herman P (2002) Exclusively endoscopic removal of juvenile nasopharyngeal angiofibroma. Trends and limits. Arch Otolaryngol Head Neck Surg 128:928-936.

11. Douglas R, Wormald PJ (2006) Endoscopic surgery for juvenile nasopharyngeal angiofibroma: where are the limits, Curr Opin Otolaryngol Head Neck Surg 14:1-5.

12. Roger G, Tran Ba Huy P, Froehlich P, Van Den Abbelle T, Klossek JM, Serrano E, arabedian EN, Herman P (2002) Exclusively endoscopic removal of juvenile nasopharyngeal angiofibroma. Rends and limits. Arch Otolaryngol Head Neck Surg 128:928-936.

\section{AUTHORS:}

1. G. Revanth Kumar Reddy

2. P. Narayana Rao

\section{PARTICULARS OF CONTRIBUTORS:}

1. Post- Graduate, Department of ENT, Guntur Medical College, Guntur.

2. Professor \& Head of the Department, Department of ENT, Guntur Medical College, Guntur.

\section{NAME ADRRESS EMAIL ID OF THE} CORRESPONDING AUTHOR:

Dr. G. Revanth Kumar Reddy

Post graduate in ENT

GGH, GUNTUR, Andhra Pradesh.

Email-revanthgangasani@gmail,com

Date of Submission: 03/07/2013.

Date of Peer Review: 03/07/2013.

Date of Acceptance: 04/07/2013.

Date of Publishing: 08/07/2013 